\title{
Pengaruh Herbisida Paraquat Diklorida Oral Terhadap Hati Tikus Putih
}

\author{
Muhartono $^{1}$, Yolanda Fratiwi ${ }^{1}$, Indri Windarti ${ }^{1}$, Susianti ${ }^{2}$
}

\begin{abstract}
The use of herbicide paraquat dichloride by farmers, is one of effort to increase the production in agricultural sector. Herbicide paraquat dichloride often used by farmers carelessly and there was caution ignorance. Herbicide cause much adverse effect to organs, especially in liver through oral. The purpose of this study is to determine the effect of oral herbicide paraquat dichloride to hepatocyte swelling and sinusoidal congestion in liver of male rats (Rattus novergicus) Sprague dawley strain. In this experimental study, 25 male rats (Rattus novergicus) Sprague dawley strain are divided randomly into 5 group and treated for 2 days. K1 is group of controlled, K2, K3, K4, K5 are given herbicide paraquat dichloride $25 \mathrm{mg} / \mathrm{kgBW}, 50 \mathrm{mg} / \mathrm{kgBW}, 100 \mathrm{mg} / \mathrm{kgBW}$, and $200 \mathrm{mg} / \mathrm{kgBW}$. The results showed that the average number of hepatocyte swelling and sinusoidal congestion in liver was increasing. In Kruskal Wallis test and Post Hoc Mann Whitney test found significant difference $\mathrm{p}=0.000(\mathrm{p}<0.005)$. There are significant effect of oral paraquat dichloride to hepatocyte swelling and sinusoidal congestion in liver of male rats (Rattus novergicus) Sprague dawley strain.
\end{abstract}

Key words: hepatocyte swelling, paraquat dichloride, sinusoidal congestion, white rats liver

Petani merupakan kelompok kerja terbesar di berbagai negara di dunia termasuk di Indonesia. Walaupun terdapat kecenderungan yang semakin menurun, angkatan kerja yang bekerja pada sektor pertanian masih berjumlah sekitar $40 \%$ dari seluruh angkatan kerja. Banyak wilayah kabupaten di Indonesia yang mengandalkan pertanian, termasuk perkebunan sebagai sumber penghasilan utama daerah. Untuk meningkatkan hasil pertanian yang optimal, dalam paket intensifikasi pertanian diterapkan berbagai teknologi, salah satunya adalah dengan penggunan agrokimia. Penggunaan agrokimia diperkenalkan secara besar-besaran menggantikan teknologi lama baik dalam hal pengendalian hama maupun pemupukan tanaman. Salah satu pola penggunaan agrokimia yang digunakan adalah pestisida. ${ }^{1}$

Pestisida merupakan bahan kimia yang telah secara luas digunakan untuk tujuan memberantas hama dan penyakit tanaman dalam bidang pertanian

\footnotetext{
1 Bagian Patologi Anatomi Fakultas Kedokteran Universitas Lampung

2 Bagian Histologi Fakultas Kedokteran Universitas Lampung
}

dan perkebunan. ${ }^{2}$ Penggunaan pestisida terbukti dapat meningkatkan kesejahteraan masyarakat baik di bidang pertanian maupun di bidang kesehatan masyarakat. Di bidang pertanian, penggunaan pestisida memungkinkan petani untuk meningkatkan produktivitas lahan pertaniannya serta mampu melindungi petani dari kerugian pasca panen. Sedangkan di bidang kesehatan masyarakat, penggunaan pestisida telah berhasil mengendalikan vektor penyakit menular tertentu, sehingga mampu menurunkan prevalensi penyakit seperti malaria, schistosomiasis, filariasis, demam berdarah dengue, dan penyakit pes. ${ }^{3}$

Laporan Organisasi Pangan Perserikatan Bangsa”Bangsa (PBB) menyatakan bahwa lebih dari 70.000 pestisida beredar di seluruh dunia dan dipergunakan secara aktif oleh para petani. Salah satu jenis pestisida yang mengalami peningkatan dalam penggunaannya di dunia adalah herbisida yaitu dari 20\% pada tahun 1960 menjadi 48\% pada tahun 2005. ${ }^{2}$ Herbisida merupakan suatu bahan atau senyawa kimia yang digunakan untuk menghambat pertumbuhan atau mematikan tumbuhan. Herbisida ini dapat mempengaruhi satu atau lebih prosesproses pertumbuhan seperti pada proses pembelahan 
sel, perkembangan jaringan, pembentukan klorofil, fotosintesis, respirasi, metabolisme nitrogen, dan aktivitas enzim yang sangat diperlukan tumbuhan untuk mempertahankan kelangsungan hidupnya. Herbisida bersifat racun terhadap gulma atau tumbuhan penganggu juga terhadap tanaman yang dibudidayakan. Herbisida yang diaplikasikan dengan konsentrasi tinggi akan mematikan seluruh bagian dan jenis tumbuhan. Pada dosis yang lebih rendah, herbisida akan membunuh tumbuhan dan tidak merusak tumbuhan yang dibudidayakan. ${ }^{4}$

Herbisida yang banyak digunakan pada bidang pertanian dan perkebunan adalah jenis herbisida paraquat (1,1"dimethyl,4,4"bipyridylium). ${ }^{5}$ Paraquat merupakan salah satu bahan aktif herbisida jenis gramoxone yang telah lama dan sampai saat ini paling banyak digunakan dalam budidaya tanaman di seluruh dunia, termasuk di Indonesia. Dipicu oleh semakin langkanya tenaga kerja dan tersedianya herbisida yang relatif mudah dan murah, peningkatan penggunaan pestisida di Indonesia, khususnya herbisida, semakin terlihat nyata pada 20 tahun terakhir. Tingginya intensitas aplikasi dan jumlah herbisida yang diaplikasikan menimbulkan kekhawatiran yang cukup besar mengenai bahaya pencemaran yang berasal dari residu herbisida yang tertinggal di lingkungan, khususnya dalam tanah dan air. Residu herbisida dalam tanah dan air dikhawatirkan akan menimbulkan gangguan kesehatan bagi manusia. ${ }^{6}$ Di negara berkembang, paraquat sering digunakan dengan sembarangan atau tidak memperhatikan bahaya serta tidak memperhatikan label peringatan sehingga dapat menyebabkan angka keterpaparan yang tinggi. Hanya dengan sedikit sendok teh paraquat, maka dapat menyebabkan kematian. Kematian dikarenakan kegagalan pernafasan, dan mungkin bisa dijumpai dalam beberapa hari setelah keracunan bahkan sampai beberapa bulan kemudian. Selain dapat menyebabkan kematian, paparan herbisida baik secara inhalasi maupun ingesti dapat menyebabkan keracunan. ${ }^{7}$

Data keracunan akibat herbisida di Amerika Serikat adalah 4,14\% dari seluruh kasus keracunan yang disebabkan oleh semua jenis pestisida. Sebanyak 0,78\% dari kasus keracunan herbisida tersebut berakibat fatal serta 27,7\% mengakibatkan korban menderita sakit. Keracunan herbisida tidak hanya menjadi permasalahan di Amerika Serikat.
Di negara berkembang, keracunan herbisida merupakan permasalahan kesehatan masyarakat dengan perkiraan sekitar 300.000 kematian di regio asia pasifik sendiri. Sebagai contoh, di Sri Lanka ada sekitar 3"400 kasus keracunan herbisida per 100.000 populasi setiap tahun. Paraquat merupakan agen penyebab kematian utama di Sri Lanka dengan angka fatalitas yang tinggi ( $>50 \%)$. Sedangkan data di Indonesia memperlihatkan sekitar 0,3\% kasus keracunan disebabkan oleh paparan herbisida. Salah satu jenis herbisida yang pernah dilaporkan menimbulkan keracunan pada manusia adalah golongan paraquat. ${ }^{4}$ Penggunaan paraquat dengan sembarangan dapat merusak berbagai macam organ diantaranya adalah jantung, ginjal, paru-paru, otot, limfa, kelenjar suprarenal, susunan saraf pusat dan juga dapat merusak hati. ${ }^{8}$ Hati merupakan organ target primer dari toksisitas paraquat baik akut maupun kronik khususnya yang masuk ke dalam tubuh secara ingesti. Hal ini dikarenakan hati merupakan organ tubuh yang penting untuk mendetoksifikasi zat kimia yang tidak berguna atau merugikan tubuh, termasuk herbisida paraquat. Hati merupakan organ yang mempunyai kemampuan untuk memetabolisme dan mengekresi beberapa zatzat kimia. $^{9}$

Proses terjadinya kerusakan pada organ hati sebagai organ yang mendetoksifikasi zat kimia seperti herbisida paraquat, dapat terjadi akibat toksisitas langsung atau melalui konversi zat kimia yang terkandung dalam herbisida paraquat menjadi toksin aktif oleh hati sehingga dapat menyebabkan timbulnya beberapa kelainan pada hati seperti pembengkakan hepatosit, kongesti sinusoid hati, fibrosis, sirosis, dan nekrosis. ${ }^{10}$ Dari uraian diatas, maka penulis tertarik untuk melakukan penelitian tentang pengaruh pemberian herbisida paraquat diklorida per"oral terhadap pembengkakan hepatosit dan kongesti sinusoid hati pada tikus putih jantan galur Sprague dawley.

\section{METODE}

Penelitian ini merupakan penelitian eksperimental laboratorik yang menggunakan metode rancangan acak terkontrol dengan pola post test only control group design. Sebanyak 25 ekor tikus putih (Rattus norvegicus) jantan galur Sprague dawley berumur 8-10 minggu yang dipilih secara 
acak, dan dibagi menjadi 5 kelompok digunakan sebagai subjek penelitian.

Kelompok 1 merupakan kelompok tikus putih yang tidak diberi herbisida paraquat diklorida per”oral. Kelompok ini digunakan sebagai kelompok kontrol. Kelompok 2 merupakan kelompok tikus putih yang diberi herbisida paraquat diklorida per"oral dengan dosis $25 \mathrm{mg} / \mathrm{kgBB}$ selama 2 hari. Kelompok 3 merupakan kelompok tikus putih yang diberi herbisida paraquat diklorida per"oral dengan dosis 50 mg/kgBB selama 2 hari. Kelompok 4 merupakan kelompok tikus putih yang diberi herbisida paraquat diklorida per"oral dengan dosis $100 \mathrm{mg} / \mathrm{kgBB}$ selama 2 hari. Kelompok 5 merupakan kelompok tikus putih yang diberi herbisida paraquat diklorida per"oral dengan dosis $200 \mathrm{mg} / \mathrm{kgBB}$ selama 2 hari.

Data yang diperoleh dari hasil pengamatan histopatologi di bawah mikroskop diuji analisis statistik. Hasil penelitian dianalisis apakah memiliki distribusi normal atau tidak secara statistik dengan uji normalitas Shapiro-Wilk karena jumlah sampel d"50. Selanjutnya dilakukan uji Levene untuk mengetahui apakah dua atau lebih kelompok data memiliki varians yang sama atau tidak. Jika varians data berdistribusi normal dan homogen, dilanjutkan dengan metode uji parametrik one way ANOVA. Bila tidak memenuhi syarat uji parametrik, digunakan uji nonparametrik KruskalWallis. Hipotesis dianggap bermakna bila $\mathrm{p}<0,050$. Jika pada uji ANOVA atau Kruskal-Wallis menghasilkan nilai $\mathrm{p}<0,050$, maka dilanjutkan dengan melakukan analisis Post-Hoc LSD atau Mann Whitney untuk melihat perbedaan antar kelompok perlakuan.

\section{HASIL}

Dari hasil analisis mikroskopis gambaran pembengkakan hepatosit didapatkan hasil rerata hepatosit yang mengalami pembengkakan dari seluruh lapangan pandang pada kelompok 1 yang hanya diberi aquades. Pada kelompok 2 yang diberikan herbisida paraquat diklorida dengan dosis 2,5 mg/100gBB didapatkan rerata hepatosit yang mengalami pembengkakan adalah sebesar 0,4. Rerata pembengkakan hepatosit pada kelompok 3 yang diberikan herbisida paraquat diklorida dengan dosis $5 \mathrm{mg} / 100 \mathrm{gBB}$ adalah sebesar 1,4. Pada kelompok 4 yang diberikan herbisida paraquat diklorida dengan dosis $10 \mathrm{mg} / 100 \mathrm{gBB}$ didapatkan rerata hepatosit yang mengalami pembengkakan pada seluruh lapangan pandang adalah sebesar 2 . Pada kelompok 5 yang diberikan herbisida paraquat diklorida dengan dosis $20 \mathrm{mg} / 100 \mathrm{gBB}$ didapatkan rerata 60 hepatosit yang mengalami pembengkakan adalah sebesar 3. Skor pembengkakan hepatosit tikus yang diberi herbisida paraquat diklorida per oral berupa rerata skala penilaian tersaji pada gambar 1.

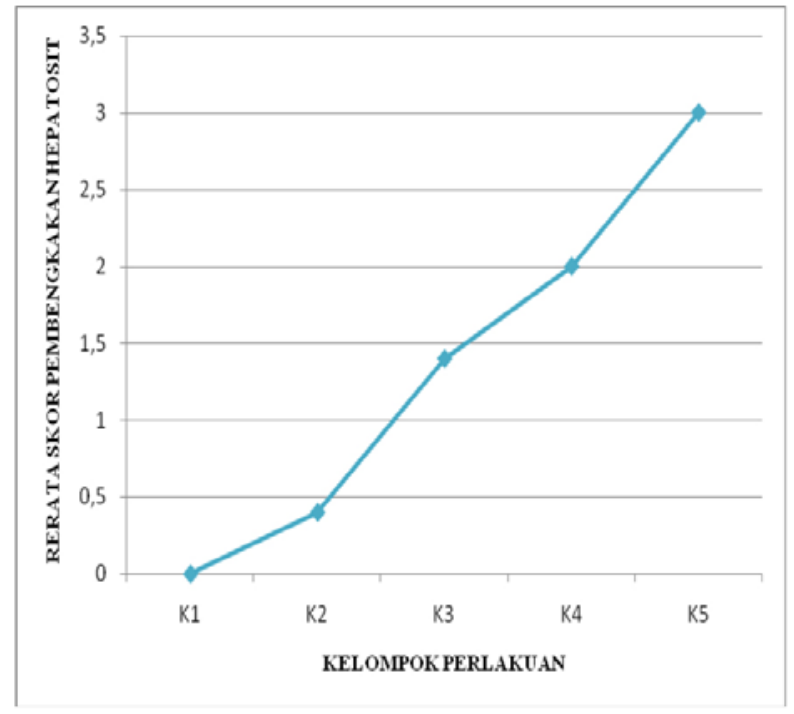

Gambar 1. Grafik perbandingan antara peningkatan dosis parakuat dengan rerata skor pembengkakan hepatosit.

Pada hasil analisis mikroskopis gambaran kongesti sinusoid didapatkan rerata sinusoid yang mengalami kongesti dari seluruh lapangan pandang pada kelompok 1 yang hanya diberi aquades. Pada kelompok 2 yang diberikan herbisida paraquat diklorida dengan dosis $2,5 \mathrm{mg} / 100 \mathrm{gBB}$ didapatkan rerata sinusoid yang mengalami kongesti adalah sebesar 0,8. Rerata kongesti sinusoid pada kelompok 3 yang diberikan herbisida paraquat diklorida dengan dosis $5 \mathrm{mg} / 100 \mathrm{gBB}$ adalah sebesar 1 . Pada kelompok 4 yang diberikan herbisida paraquat diklorida dengan dosis $10 \mathrm{mg} / 100 \mathrm{gBB}$ didapatkan rerata sinusoid yang mengalami kongesti adalah sebesar 2. Pada kelompok 5 yang diberikan herbisida paraquat diklorida dengan dosis $20 \mathrm{mg} / 100 \mathrm{gBB}$ didapatkan rerata sinusoid yang mengalami kongesti adalah sebesar 3. Skor kongesti sinusoid hati tikus yang diberi herbisida paraquat diklorida per"oral 
berupa rerata skala penilaian tersaji pada gambar 2 . Berdasarkan grafik pada gambar 2, terlihat peningkatan kongesti sinusoid pada setiap kelompok tikus sesuai dengan peningkatan dosis herbisida paraquat diklorida yang diberikan pada masingmasing tikus pada setiap kelompok.

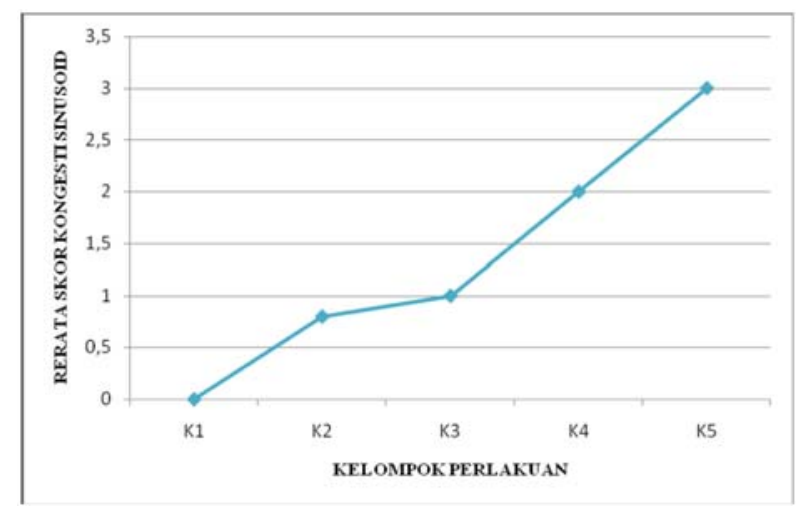

Gambar 2. Grafik perbandingan antara peningkatan dosis parakuat dengan rerata skor kongesti snusoid.

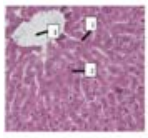

K1

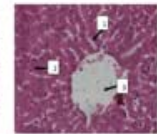

K2

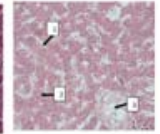

K3

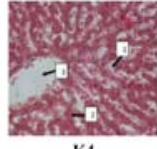

$\mathrm{K} 4$

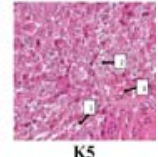

K5
Gambar 3. Histopatologi parenkim paru pada berbagai perlakuan.

\section{PEMBAHASAN}

Berdasarkan hasil pengamatan mikroskopis dengan pembesaran 100x dan 400x didapatkan bahwa pada kelompok 1 yang merupakan kelompok kontrol negatif memiliki perbedaan gambaran mikroskopis pembengkakan hepatosit dan kongesti sinusoid yang signifikan dengan kelompok lain. Hasil yang didapatkan sejalan dengan penelitian sebelumnya yang dilakukan oleh Malekinejad et al $(2013)^{10}$ yaitu terdapat gambaran hepatosit yang masih tersusun radier, dengan bentuk yang normal tanpa mengalami pembengkakan. Pada gambaran sinusoid juga tampak normal dan tidak terjadi kongesti. Hal ini dikarenakan pada kelompok 1 hanya diberikan aquades yang tidak bersifat toksik dan tidak mengandung zat oksidan.

Pada kelompok 2 yang diberikan herbisida paraquat diklorida dengan dosis 2,5 mg/100gBB didapatkan rerata pembengkakan hepatosit adalah sebesar 0,4 dan rerata kongesti sinusoid adalah sebesar 0,8. Hasil analisa tersebut menunjukkan bahwa kelompok 2 memiliki perbedaan yang signifikan terhadap pembengkakan hepatosit dan kongesti sinusoid yang terjadi pada kelompok 3, 4, dan 5. Gambaran mikroskopis yang terlihat pada kelompok 2 menunjukkan pembengakakan hepatosit dan kongesti sinusoid yang mulai terjadi tetapi sebagian besar hepatosit dan sinusoid dalam seluruh lapangan pandang masih menunjukkan keadaan normal. Hal tersebut sejalan dengan penelitian yang dilakukan oleh Juhryyah (2008) ${ }^{11}$ dan Malekinejad et al (2013) $)^{10}$ bahwa pemberian herbisida paraquat diklorida dengan dosis terendah akan terlihat hepatosit mengalami pembengkakan ringan dan kongesti sinusoid ringan tetapi secara keseluruhan belum terlihat perubahan yang signifikan.

Pada kelompok 3 yang diberikan herbisida paraquat diklorida dengan dosis $2 \mathrm{mg} / 100 \mathrm{gBB}$ didapatkan rerata pembengkakan hepatosit adalah sebesar 1,4 dengan rerata kongesti sinusoid sebesar 1. Dari rerata tersebut dapat diketahui bahwa terjadi peningkatan pembengkakan hepatosit dan kongesti sinusoid pada kelompok 3 dibandingan dengan kelompok 2. Perubahan gambaran mikroskopis yang terlihat lebih signifikan dibandingkan dengan kelompok 2 ditandai dengan adanya pembengkakan hepatosit dan kongesti sinusoid di sekitar vena sentral.

Pada kelompok 4 yang diberikan herbisida paraquat diklorida dengan dosis $10 \mathrm{mg} / 100 \mathrm{gBB}$ didapatkan rerata pembengkakan hepatosit adalah sebesar 2 dengan rerata kongesti sinusoid sebesar 2. Dari rerata tersebut dapat diketahui bahwa terjadi peningkatan pembengkakan hepatosit dan kongesti sinusoid yang lebih signifikan pada kelompok 4 dari rerata pada kelompok 2 dan 3 . Peningkatan tersebut ditandai dengan adanya pembengkakan hepatosit dengan susunan yang tidak teratur dan kongesti sinusoid di sekitar vena sentral dan lebih lebar dari kelompok 2 dan 3.

Pada kelompok 5 yang diberikan herbisida paraquat diklorida dengan dosis $20 \mathrm{mg} / 100 \mathrm{gBB}$ didapatkan rerata pembengkakan hepatosit adalah sebesar 3 dengan rerata kongesti sinusoid sebesar 3. Dari rerata tersebut dapat diketahui bahwa terjadi peningkatan pembengkakan hepatosit dan kongesti 
sinusoid yang lebih signifikan pada kelompok 5 dari rerata pada kelompok 2, 3, dan 4 . Peningkatan tersebut ditandai dengan adanya pembengkakan hepatosit dengan susunan yang tidak teratur, sitoplasma dan intisel yang tidak jelas serta kongesti sinusoid di sekitar vena sentral yang meluas hingga ke vena porta.

Pada kelompok 2, 3, 4, dan 5 terlihat pembengkakan hepatosit dan kongesti sinusoid dengan keparahan yang semakin meningkat sesuai dengan peningkatan dosis herbisida paraquat diklorida yang diberikan pada setiap tikus pada masing-masing kelompok tersebut. Peningkatan derajat keparahan pembengkakan hepatosis tersebut disebabkan oleh zat oksidan atau radikal bebas yang berasal dari hasil proses reoksidasi kandungan herbisida paraquat diklorida. Peningkatan dosis yang diberikan pada setiap kelompok akan menyebabkan terjadinya peningkatan pada zat oksidan yang direoksidasi di dalam sel hati. Zat oksidan atau radikal bebas tersebut akan menyebabkan hilangnya regulasi intraseluler oleh $\mathrm{Ca} 2+$ dan ATPase. Hilangnya regulasi tersebut akan menyebabkan gangguan kemampuan sel untuk melakukan transport aktif ion natrium keluar sel yang berakibat masuknya air dalam jumlah berlebihan ke dalam sel. Hilangnya regulasi intraseluler juga akan menyebabkan kerusakan pada membran hepatosit sehingga hepatosit akan mengalami pembengkakan. ${ }^{11,12}$

Pembengkakan hepatosit tidak hanya terjadi pada bagian retikulum endoplasma dan mitokondria tetapi air juga berkumpul dalam rongga-rongga sel. Secara mikroskopis, akan tampak vakuol-vakuol yang jernih tersebar dalam sitoplasma. Terkadangan vakuol-vakuol kecil bersatu membentuk vakuol lebih besar sehingga inti terdesak ke pinggir. Pembengkakan hepatosit yang terjadi pasca pemberian herbisida paraquat diklorida cukup parah, vakuol yang terbentuk berupa vakuol-vakuol kecil dan sedikit vakuol besar tetapi belum mendesak inti ke pinggir. Perubahan ini bersifat reversibel, yaitu jika rangsangan yang menimbulkan cedera dihentikan, sel-sel akan kembali normal. ${ }^{10,11}$

Kongesti sinusoid dengan keparahan yang semakin meningkat sesuai dengan peningkatan dosis herbisida paraquat diklorida yang diberikan pada setiap tikus pada masing-masing kelompok disebabkan oleh pemberian herbisida paraquat diklorida yang merupakan zat toksik yang dapat mengganggu sistem sirkulasi sehingga sel-sel kekurangan oksigen dan zat-zat makanan. Kongesti adalah suatu keadaan meningkatnya volume darah dalam pembuluh darah yang melebar. Kongesti terjadi melalui dua mekanisme yaitu kenaikan jumlah darah yang mengalir ke sinusoid atau penurunan jumlah darah yang mengalir dari sinusoid. Jika aliran darah ke dalam daerah sinusoid bertambah dan menimbulkan kongesti, maka disebut kongesti aktif. Apabila kongesti disebabkan karena gangguan aliran darah disebut dengan kongesti pasif. Peningkatan kongesti sinusoid yang terjadi secara signifikan dimulai dari kelompok 2 sampai dengan kelompok 5 dapat dikategorikan sebagai kongesti sinusoid pasif yang disebabkan oleh zat toksik yang terkandung dalam herbisida paraquat diklorida mengganggu sistem sirkulasi. ${ }^{12}$

\section{SIMPULAN}

Terdapat pengaruh pemberian herbisida paraquat diklorida per"oral terhadap pembengkakan hepatosit pada tikus putih (Rattus norvegicus) jantan galur Sprague dawley. Terdapat pengaruh pemberian herbisida paraquat diklorida per"oral terhadap kongesti sinusoid hati pada tikus putih (Rattus norvegicus) jantan galur Sprague dawley.

\section{DAFTAR PUSTAKA}

1. Prijanto TB. 2009. Analisis faktor resiko keracunan pestisida organofosfat pada keluarga petani holtikultura di Kecamatan Ngablak Kabupaten Magelang. Tesis. Semarang: Universitas Diponegoro.

2. Zhang W, Jiang F, Ou J. 2011. Global pesticide consumption and pollution: with China as a focus. Proceedings of the International Academy of Ecology and Enviromental Sciences. 1(2):216.

3. Saftarina F. 2011. Analisis keracunan pestisida pada petani padi di desa RJ Bandar Lampung. Jurnal Kedokteran dan Kesehatan Universitas Lampung. 1(1):61-69.

4. Sembodo DRJ. 2010. Gulma dan pengelolaannya. Bandar Lampung: Graha Ilmu. 
5. Viaiudiana RA. 2013. Pengaruh bentonit terhadap kadar malondialdehye (mda) jaringan ginjal rattus norvegicus yang dipapar herbisida paraquat. Skripsi. Malang: Universitas Brawijaya.

6. Sriyani N, Salam AK. 2008. Penggunaan metode bioassay untuk mendeteksi pergerakan herbisida pascatumbuh paraquat dan 2,4"D dalam tanah. Jurnal Tanah Tropika. 13(3):199"208.

7. Ginting AW, Endang S, Saut Marpaung, Ginting F, Kembaren T, Rahimi A, et al. 2012. Intoksikasi herbisida (paraquat). IKAAPDA (Ikatan Keluarga Asisten Penyakit Dalam).

8. Moon JM, Chun BJ. 2011. The efficacy of high doses of vitamin $C$ in patients with paraquat poisoning. Human and Experimental Toxicology. 30(8):844"50.
9. Mansur. 2008. Toksikologi dan distribusi agent toksik. Edisi ke”2. Jakarta: UI Press.

10.Malekinejad H, Rezabakhsh A, Rahmani F, Razi M. 2013. Paraquat exposure up-regulates cyclooxygenase- 2 in the lungs, liver and kidney in rats. Iranian Journal of Pharmaceutical Research. 12(4):887"96.

11.Juhryyah S. 2008. Gambaran Histopatologi organ hati dan ginjal tikus pada intoksikasi akut insektisida (Metofluthrin, D-phenothrin, Dallethrin) dengan dosis bertingkat. Skripsi. Bogor. Institut Pertanian Bogor.

12.Price SA, Lorraine MW. 2006. Patofisiologi konsep klinis proses-proses penyakit. Jakarta: EGC. Terjemahan dari: Pathophysiology Clinical Concepts of Disease Processes. 